\title{
Genetic resistance to powdery mildew in common bean
}

\author{
N. Trabanco $\cdot$ E. Pérez-Vega $\cdot$ A. Campa $\cdot$ \\ D. Rubiales $\cdot$ J. J. Ferreira
}

Received: 22 November 2011/Accepted: 10 March 2012/Published online: 5 April 2012

(C) Springer Science+Business Media B.V. 2012

\begin{abstract}
Powdery mildew can cause severe yield losses in bean crops. Limited information about resistance sources, and nature and inheritance of resistance are available to bean breeders and plant pathologist. Sources of resistance were searched in seedling tests under controlled conditions in 44 well-known genotypes and in a Spanish germplasm core collection consisting on 201 accessions. A 0-4 scale was used to describe the infection types (IT) observed. Only six out of the 245 evaluated genotypes showed a complete resistance (IT0) without visible symptoms on the leaves: Amanda, Belneb, Cornell 49242, Negro San Luis, Porrillo Sintetico and the local accession BGE003161. Inheritance of resistance was studied in $F_{2}$ and $F_{2: 3}$ segregating populations. Observed reactions in the five segregating populations fitted to Mendelian ratios with different modes of inheritance. Results revealed that cultivar Porrillo Sintetico carries two dominant and independent
\end{abstract}

E. Pérez-Vega and N. Trabanco contributed equally to this study.

N. Trabanco · E. Pérez-Vega · A. Campa ·

J. J. Ferreira $(\bowtie)$

Área de Cultivos Hortofrutícolas y Forestales, SERIDA, Apdo. 13, 33300 Villaviciosa (Asturias), Spain

e-mail: jjferreira@serida.org

D. Rubiales

Instituto de Agricultura Sostenible, CSIC, Apdo. 4084, 14080 Córdoba, Spain resistance genes: one gene conferring complete resistance (IT0), and another gene conferring IT3, characterized by a moderate mycelial development on the leaves. Both genes show a dominant epistatic relationship. Inheritance of response to powdery mildew in cv. Cornell 49242 was similar to cv. Porrillo Sintetico although the correspondence with the genes described in Porrillo Sintetico was not established. Line X2776 carries one dominant gene conferring IT3, and shares this gene with cv. Porrillo Sintetico. In cv. Amanda, two complementary genes appear to be involved in resistance to this fungus. This information will be relevant for the implementation of breeding programs focused on the development of cultivars carrying genetic resistance to powdery mildew.

Keywords Resistance sources · Plant-fungus interaction - Inheritance of resistance $\cdot$ Plant breeding

\section{Introduction}

Powdery mildew is a serious disease for many crops worldwide including common bean (Phaseolus vulgaris $\mathrm{L}$.). Common bean powdery mildew causal agent has been frequently ascribed to Erysiphe poligony DC. (Ferreira et al. 1999) but recent studies suggest that it is closer to Erysiphe diffusa (Cooke \& Peck) U. Braun \& S. Takam, formerly Microsphaera diffusa Cke. \& Pk. (Almeida et al. 2008). Powdery mildews are obligate biotroph fungi that affect all aerial parts of the 
bean plant. The disease is usually first noted as subtle, small, round, greyish or whitish spots on leaves or stems (Schwartz 2005). Progression of the disease leads to enlargement of the spots and coalescinge to a white mass resembling talcum powder on the upper leaf surface, especially in older parts of the plant. On the pods, the fungus can produce greyish cankers. The entire plant can be covered by cottony fungal mycelia and premature senescence of leaves and pods may occur. In the last years the incidence of powdery mildew has significantly increased in bean crops of northern Spain. Under field conditions, fungus colonies appear on bean crops in mid to late July and spread rapidly, colonizing entire leaf surfaces and stems. Conventional methods based on fungicide application have not been efficient in disease control.

The use of resistant bean cultivars can be the most efficient, economical and ecological strategy to provide effective control of this disease. Limited information about sources of resistance to the fungus and the nature and inheritance of resistance are available to bean breeders and plant pathologist. A few sources of resistance to powdery mildew have been described (Schwartz et al. 1981), and a qualitative nature of resistance has been suggested (Bett and Michaels 1995; Ferreira et al. 1999, 2001). The response of common bean to powdery mildew was previously reported to be governed either by a single dominant gene (Dundas 1936); by one dominant and another recessive resistance genes (Bett and Michaels 1995); or by two complementary dominant genes (Ferreira et al. 1999). In general, plant response to powdery mildew has been studied in evaluations carried out in naturally infected fields. However, resistance tests performed under controlled conditions are preferable to ensure repeatable results of the analysis of plantpathogen interaction (Sillero et al. 2006). In other species, resistance tests developed under controlled conditions and qualitative scales have been used to score the response to powdery mildew (Fondevilla et al. 2006) but this was not applied before in common bean-powdery mildew interaction.

Core collections are usually recommended for the identification of potential sources of resistance against pathogens as well as for the validation of new descriptors, such as the response to plant-pathogen interaction (van Hintum et al. 2000; Pascual et al. 2010). Segregating populations are also a useful tool to investigate the qualitative or quantitative nature of reaction against pathogens as well as to analyze the inheritance. Both sets of materials can also help to test screening methods.

The objectives of this study were to (i) identify resistance sources against powdery mildew in common bean, and (ii) determine the nature of resistance. This information can be of interest for plant breeding programs focused on the introgression of genetic resistance to powdery mildew in bean genotypes.

\section{Materials and methods}

\section{Plant material}

A total of 245 bean accessions maintained at the Servicio Regional de Investigación y Desarrollo Agroalimentario (SERIDA, Villaviciosa, Asturias, Spain) germplasm collection were screened for reaction to a local isolate of powdery mildew. The evaluated materials included 201 accessions of the core collection established from the main bean genebank in Spain (Pérez-Vega et al. 2009), and 44 well-known genotypes, cultivars (cvs.) or breeding lines, including: eleven cvs. used for anthracnose [Colletotrichum lindemuthianum (Sacc. \& Magnus) Lams.-Scrib] race characterization: Michelite, Michigan Dark Red Kindey (MDRK), Perry Marrow, Cornell 49242, Mexico 222, Widusa, Kaboon, PI207262, TO, TU and AB136 (Pastor-Corrales 1991); four lines used as resistant sources to anthracnose: A252, A321, A483, and A493 (Ferreira et al. 2008); seven cvs. used for characterization of the pathogenic variability of Bean common mosaic virus (BCMV) and Bean common mosaic necrosis virus (BCMNV): Amanda, Dubbele Witte, Great Northern 31, Imuna, Jubila, Pinto 114, and Topcrop (Drijfhout 1978); four genotypes described as resistant sources to BCMV and BCMNV: Don Timoteo, BRB57, BRB130, and IVT7214; five lines described with moderate levels of resistance to white mold [Sclerotinia sclerotiorum (Lib.) de Bary]: A195, G122, Cornell 606, MO-162, and PC 50 (Pascual et al. 2010); the lines BAT93 and Jalo EEP558 used as parents of a major core mapping population (Freyre et al. 1998); four cultivars included in the market class fabada and developed at SERIDA, Andecha, A2806, Xana, and X2776; the cvs. Sanilac and Tendergreen commonly used as reference for the two major gene pools, Middle American and Andean 
(Gepts et al. 1986); genotypes A55, Negro San Luis, Belneb, and Chinook described with high levels of resistance to soil pathogens (Román-Avilés and Kelly 2005); and Porrillo Sintético, a genotype described as resistant to powdery mildew (Schwartz et al. 1981).

Five $F_{2}$ populations derived from the crosses Xana $\times$ Cornell 49242, Xana $\times$ Porrillo Sintético, Amanda $\times$ Xana, X2776 $\times$ G122, and Porrillo Sintético $\times$ X2776 were evaluated to investigate the inheritance of the response to powdery mildew. In order to verify the mode of inheritance, $83 \mathrm{~F}_{2: 3}$ families (obtained by selfing individuals $F_{2}$ plants) derived from the cross between the susceptible cv. Xana and the resistant cv. Porrillo Sintético were also evaluated. At least twenty $\mathrm{F}_{3}$ plants per family were evaluated to characterize the corresponding $F_{2}$ plants for resistance to powdery mildew. Number of evaluated $\mathrm{F}_{3}$ plants was increased in six families to confirm the mode of inheritance.

Inoculation procedure and disease scoring

A local isolate of powdery mildew obtained from a single spot in one infected bean plant at Villaviciosa, Asturias (northern Spain) was used in this study. The pathogen isolate was maintained on plants of susceptible bean cv. Xana in spore-proof chambers. Sequence analysis of ITS region revealed a high similarity of this local isolate with the species
Erysiphe diffusa (N. Rispail per. com.) which is in agreement with Almeida et al. (2008).

Four seeds of each genotype were planted in a $15 \mathrm{~cm}$ plastic pot, 1.51 volume, containing 80 peat:20 perlite. When the primary leaves were fully developed, seedlings were inoculated by blowing conidia directly from infected leaves onto test plants to give a density of about 5-10 spores $/ \mathrm{cm}^{2}$. Inoculations were performed in sets of 25 pots placed in a box $(80 \mathrm{~cm} \times 80 \mathrm{~cm} \times 80 \mathrm{~cm})$. To verify the inoculation procedure, a pot containing susceptible genotype Xana was included in each set as control. Inoculated plants were transferred to another greenhouse and they were maintained at moderate temperature $\left(18-24{ }^{\circ} \mathrm{C}\right)$ and moderate relative humidity (60-70\%). Only inoculated sets in which control Xana showed symptoms were considered. Plant response was recorded as infection type (IT) following a 0-4 scale (Fig. 1) adapted from Mains and Dietz (1930): IT0, seedlings with no visible symptoms; IT1, seedlings with necrotic reaction on leaves with little or no mycelial development; IT2, seedlings with necrotic reaction and moderate mycelial development; IT3, seedlings with moderate mycelial development on leaves without sporulation; IT4, seedlings with abundant mycelial development on leaves and profuse sporulation. Disease assessment was performed 12 days after inoculation when the susceptible control exhibited visible symptoms. Each plant in the pot was rated separately.
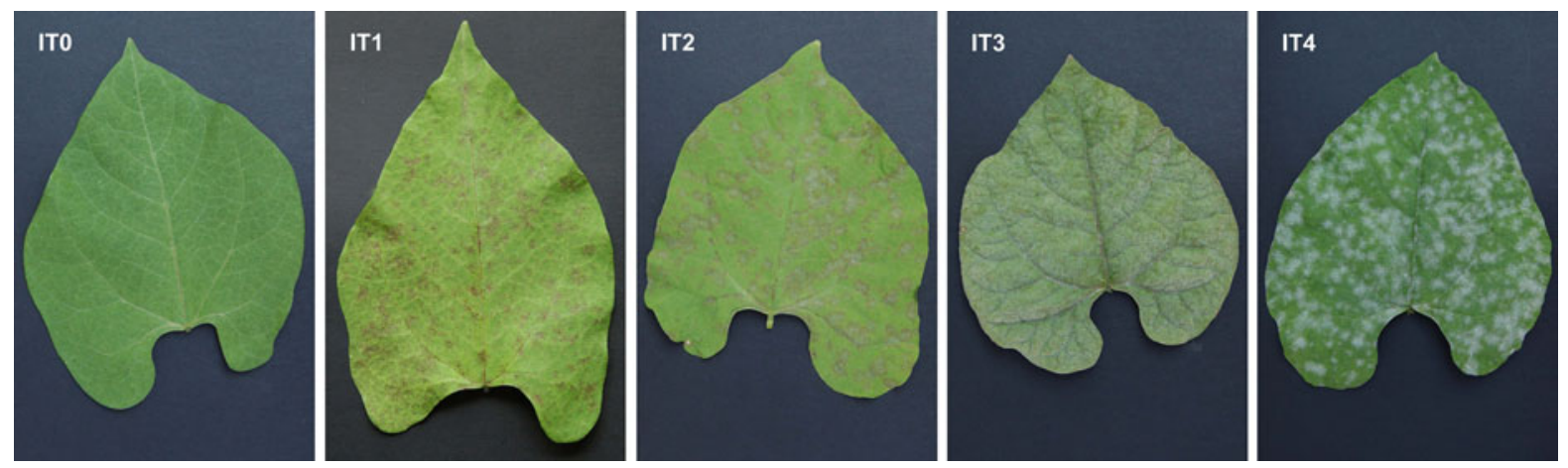

Fig. 1 The five infection types (IT) considered in the classification of response to powdery mildew in common bean: ITO primary leaf with no visible symptoms (cv. Porrillo sintético), IT1 primary leaf with necrotic reaction and no mycelial development (cv. TO), IT2 primary leaf with necrotic reaction and moderate mycelial development (line A195), IT3 primary leaf with moderate mycelial development and no sporulation (line X2776), IT4 primary leaf with abundant mycelial development and profuse sporulation (cv. Xana) 
Experimental design and data analysis

Three tests were performed to investigate the reaction of bean materials. In each test, two pots per genotype or accession were arranged in a randomized design. Genotypes or accessions showing different infection types in the same test were considered as mixtures. Genotypes or accessions showing different scores among tests were evaluated in a fourth test and classified according to the most frequent response.

Segregating $\left(\mathrm{F}_{2}\right.$ or $\left.\mathrm{F}_{2: 3}\right)$ populations were evaluated in two different tests, including the corresponding parents. Chi-square was used to test goodness-of-fit of observed to expected ratios.

\section{Results}

Response of well-known genotypes

Results presented in Table 1 shows that various types of responses are present in this set of bean genotypes. Five cvs. (Amanda, Belneb, Cornell 49242, Negro San Luis, and Porrillo Sintético) showed complete resistance with no symptoms (IT0). Breeding lines A195, A321, BRB130 and cv. TO displayed high levels of resistance based on macroscopically visible hypersensitive response (IT1 or IT2). Four genotypes (A2806, AB136, Chinook, and X2776) exhibited intermediate resistance based on a diffuse pathogen growth on the leaf (IT3). Cultivar Jubila showed a mixed infection type (IT0/IT4). Thirty remaining genotypes were very susceptible showing symptoms similar to those of the susceptible control Xana (IT4).
Response of the core collection accessions

A total of 201 accessions included in a core collection were screened for their reaction against the local isolate of powdery mildew. Results are shown in Fig. 2. Most of the accessions (146) showed IT4, with clear symptoms and conidia production, like the susceptible control Xana. Ten accessions exhibited IT3 with moderate mycelial development on leaves without profuse sporulation. Clear necrotic reactions on leaves (IT1) were observed in seven accessions, and in 28 accessions the necrotic reaction occurred together with limited pathogen growth (IT2). Infection type 0 (seedlings with no visible symptoms) was only observed in the local accession BGE003161 which has small, oval, and cream colour seeds (30 g/100 seeds)

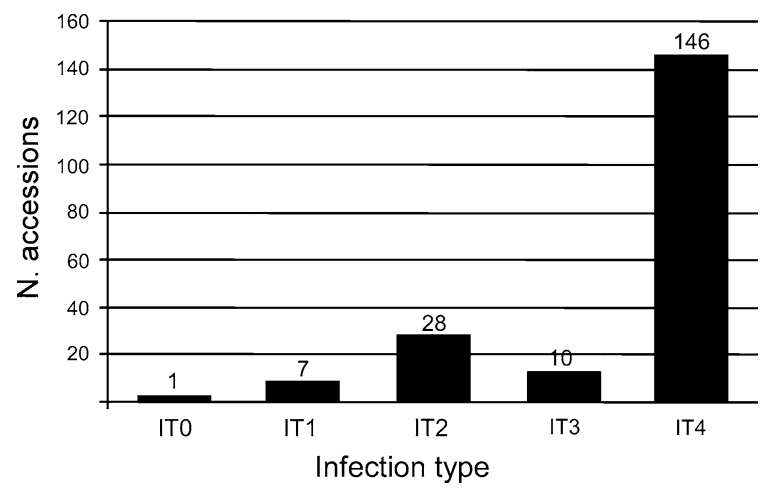

Fig. 2 Histogram showing the distribution for the reaction to a local isolate of powdery mildew for bean accessions included in the core collection described by Pérez-Vega et al. (2009). The nine accessions showing evidences of mixture in the reaction, were not included

Table 1 Reaction of 44 common bean genotypes against a local isolate of powdery mildew observed in three separate tests

\begin{tabular}{ll}
\hline $\begin{array}{l}\text { Infection type } \\
\text { (IT) }\end{array}$ & Genotypes \\
\hline 0 & Amanda, Belneb, Cornell 49242, Negro San Luis, Porrillo Sintetico \\
1 & A195 \\
2 & A321, BRB130, TO \\
3 & A2806, AB136, Chinook, X2776 \\
4 & A252, A483, A493, A55, Andecha, BAT93, BRB57, Cornell 606, Don Timoteo, Dubbele Witte, G122, Great \\
& Northerm 31, Imuna, IVT7214, JALO EEP558, Jubila , Kaboon, MDRK, Mexico 222, Michelite, MO162, PC50, \\
& Perry Marrow, PI207262, Pinto 114, Sanilac, Tendergreen, Topcrop, TU, Widusa, Xana
\end{tabular}

Plant response was classified in five classes; ITO with no visible symptoms, IT1 seedlings with necrotic reaction on leaves, IT2 necrotic reaction together with limited growth of the pathogen on leaves, IT3 diffuse growth and no sporulation, IT4 abundant mycelial development on leaves and profuse sporulation

a Jubila showed mixture of IT0 and IT4 
and an indeterminate prostrate growth habit. A mixture in infection type was observed in nine accessions and one of them, BGE022510, included seedlings with IT0 (8 plants) and IT4 (16 plants).

Inheritance of the response

To investigate the genetic control of resistance and to verify the consistence of the 0-4 scale used, the reaction to powdery mildew was analyzed in five $F_{2}$ segregating populations. Reaction of the $\mathrm{F}_{2}$ seedlings was classified according to the $0-4$ scale, suggesting a qualitative nature of resistance. Table 2 shows the observed segregations for the reaction to the local isolate of powdery mildew. Two tests were carried out and the observed segregation of each $\mathrm{F}_{2}$ population fitted to the same Mendelian ratio in both tests.

Three types of responses were observed in the $F_{2}$ plants derived from the crosses Xana (IT4) $\times$ Cornell 49242 (IT0) and Xana (IT4) $\times$ Porrillo Sintetico (IT0): IT0, IT3, and IT4. IT0 was the most common reaction. Observed segregations showed no significant differences when compared to the expected ratio for two independent dominant genes (12 IT0: 3 IT3: 1 IT4): a gene conferring IT0, and another gene conferring IT3. Both genes showed a dominant epistatic relationship, so that expression of the second gene is masked by the dominant effect of the first gene.

In the two tests, $\mathrm{F}_{2}$ segregating population derived from the cross Porrillo Sintético (IT0) $\times$ X2776 (IT3), $\mathrm{F}_{2}$ plants showed parental responses, with IT0 as the most common reaction (Table 2). The segregation ratio fitted to the expected ratio for one dominant gene (3 IT0: 1 IT3) suggesting that both parents differ in a dominant gene controlling the reaction IT0.

Two types of responses were observed in $\mathrm{F}_{2}$ plants derived from the cross X2776 (IT3) $\times$ G122 (T4): IT3 and IT4. Infection type 3 was the most common response (Table 2). Observed segregation fitted to the expected ratio for one dominant gene (3 IT3:1 IT4) suggesting that IT3 is controlled by a dominant gene in X2776.

Parental infection types were also observed in the $\mathrm{F}_{2}$ segregating population derived from the cross Amanda (IT0) $\times$ Xana (IT4) and observed segregation fitted to a 9 (IT0): 7 (IT4) ratio, expected in the case of two complementary dominant genes.

Genetic dissection of resistance in Porrillo Sintetico

In order to confirm that two different genes are involved in the response of Porrillo Sintetico, a $F_{2: 3}$ population obtained from the cross Porrillo Sintético $\times$ Xana was evaluated in detail. The following results were observed: 28 families with all $\mathrm{F}_{3}$ plants showing IT0; 26 families including $\mathrm{F}_{3}$ plants with IT0, IT3 and/or IT4; 12 families including $\mathrm{F}_{3}$ plants with IT0 and IT4; 8 families including $\mathrm{F}_{3}$ plants with IT3 and IT4; 2 families with all $\mathrm{F}_{3}$ plants showing IT3; 7 families with all $\mathrm{F}_{3}$ plants showing IT4. Expected ratio in the case of two dominant and independent genes

Table 2 Observed segregation in five $\mathrm{F}_{2}$ populations derived from crosses among common bean parents with different types of reaction against a local isolate of powdery mildew

\begin{tabular}{|c|c|c|c|c|c|c|c|c|c|}
\hline \multirow[t]{2}{*}{ Parent $1 \times$ Parent 2} & \multicolumn{2}{|c|}{ Response of parents (IT) } & \multirow[t]{2}{*}{ Test } & \multicolumn{3}{|c|}{ Observed segregation } & \multirow[t]{2}{*}{ Expected ratio } & \multirow[t]{2}{*}{$\chi^{2}$} & \multirow[t]{2}{*}{$P$-value } \\
\hline & Parent 1 & Parent 2 & & IT0 & IT3 & IT4 & & & \\
\hline \multirow[t]{2}{*}{ Xana $\times$ Cornell 49242} & 4 & 0 & 1 & 55 & 13 & 10 & $12: 3: 1$ & 5.78 & 0.06 \\
\hline & & & 2 & 51 & 12 & 4 & $12: 3: 1$ & 0.00 & 0.98 \\
\hline \multirow[t]{2}{*}{ Xana $\times$ Porrillo Sintético } & 4 & 0 & 1 & 76 & 23 & 5 & $12: 3: 1$ & 1.18 & 0.55 \\
\hline & & & 2 & 96 & 19 & 2 & $12: 3: 1$ & 5.02 & 0.08 \\
\hline \multirow[t]{2}{*}{ Amanda $\times$ Xana } & 0 & 4 & 1 & 46 & - & 36 & $9: 7$ & 0.01 & 0.92 \\
\hline & & & 2 & 12 & - & 13 & $9: 7$ & 0.69 & 0.40 \\
\hline \multirow[t]{2}{*}{$\mathrm{X} 2776 \times \mathrm{G} 122$} & 3 & 4 & 1 & - & 91 & 24 & $3: 1$ & 1.29 & 0.26 \\
\hline & & & 2 & - & 73 & 23 & $3: 1$ & 0.00 & 0.81 \\
\hline \multirow[t]{2}{*}{ Porrillo Sintético $\times$ X2776 } & 0 & 3 & 1 & 65 & 16 & - & $3: 1$ & 1.19 & 0.27 \\
\hline & & & 2 & 80 & 25 & - & $3: 1$ & 0.11 & 0.73 \\
\hline
\end{tabular}

$I T$ infection type 
(A,a and $\mathrm{B}, \mathrm{b})$ with a dominant epistatic relationship is, $4\left(\mathrm{~F}_{2}\right.$ genotype, $A A-$; observed infection type in $\mathrm{F}_{3}$ families, 0): 6 ( $A a B B / A a B b$; IT0/IT3/IT4): 2 ( $A a b b$; IT0/IT4) 2 ( $a a B b$; IT3/IT4): 1 (aaBB; IT3): 1 (aabb; IT4). The observed ratio of these six classes fitted to expected ratio for this hypothesis $\left(\chi^{2}=6.78\right.$, $P=0.24)$. Number of evaluated $\mathrm{F}_{3}$ plants were incremented in six $F_{3}$ families with monogenic segregation to verify this hypothesis (Table 3): $F_{3}$ families 59 and 63 exhibited a segregation for IT0 and IT4; $\mathrm{F}_{3}$ families 22 and 71 exhibited a segregation for IT0 and IT3; $F_{3}$ families 37 and 95 exhibited a segregation for the reaction types 3 and 4 . In all cases, observed segregations showed no significant differences when compared to the expected ratio for one dominant gene, confirming that Porrillo Sintetico carries two dominant and independent genes.

\section{Discussion}

We adopted a qualitative scale including five phenotypic classes to classify reactions of common bean germplasm to powdery mildew. To our knowledge, this qualitative scale has never been tested before in common bean although a similar qualitative scale was used to record the response against powdery mildew in barley germplasm (Mains and Dietz 1930; Shtaya et al. 2007). Previous studies investigating beanpowdery mildew interactions used a 1-9 quantitative scale based on percentage of the leaf area covered by mycelium to assess the response in field tests (Ferreira et al. 1999). Our results reveal that the responses of bean germplasm, well-known genotypes and segregating populations can be classified in any of the five defined classes. Limited variations in the response among tests were observed in some genotypes.
Observed variation was between IT3 and IT4 (e.g. accessions BGE003208 and BGE003246) or IT1 and IT2 (e.g. A321, BRB130 and TO). Environmental factors such as humidity, temperature or light can influence development of the disease, possibly explaining these differences in scores, especially the necrotic reaction. Expression of resistance to powdery mildew associated with high temperatures $\left(25^{\circ} \mathrm{C}\right)$ was described in pea (Fondevilla et al. 2006).

Plant responses of genotypes Cornell 49242, Porrillo Sintético, A195, G122, A2806, AB136, MDRK, Andecha or X2776 observed under controlled conditions were similar to those observed in naturally infected fields at Villaviciosa, Asturias (northern Spain). Genotypes with IT0 such as cvs. Cornell 49242 or Porrillo Sintético did not show symptoms under field conditions, in naturally infected fields. Genotypes with IT1, IT2 or IT3 exhibited limited mildew growth in the field, not affecting the plant development. Genotypes with IT4, such as cvs. Andecha, Xana, G122 or MDRK, showed symptoms in all aerial parts of the plants, as well as leaf drop and premature death when grown in naturally infected fields.

The observed reactions in the $F_{2}$ segregating populations analyzed in this study indicate a qualitative nature of resistance to powdery mildew, supporting previous reports (Dundas 1936; Bett and Michaels 1995; Ferreira et al. 1999). A qualitative response in the interaction powdery mildew- common bean is not surprising, since this type of response has already been reported in other legume species such as pea (Pisum sativum L.) (Fondevilla et al. 2008; Katoch et al. 2010), mungbean (Vigna radiata L. Wilczek; Reddy et al. 1994), or soybean ((Glycine max L. (Merr.)) (Lohnes and Bernard 1992; Kang and Rouf Mian 2010).

From observed segregations, it is possible to conclude that several resistance genes controlling
Table 3 Observed segregation in six $\mathrm{F}_{2: 3}$ families derived from crosses Xana $\times$ Porrillo Sintético

\begin{tabular}{lllllll}
\hline F 3 families & \multicolumn{2}{l}{ Observed segregation } & & Expected ratio & $\chi^{2}$ & $P$-value \\
\cline { 2 - 5 } & IT0 & IT3 & IT4 & & & \\
\hline F3-59 & 52 & - & 15 & $3: 01$ & 0.24 & 0.62 \\
F3-63 & 43 & - & 16 & $3: 01$ & 0.14 & 0.71 \\
F3-22 & 42 & 13 & - & $3: 01$ & 0.00 & 0.81 \\
F3-71 & 48 & 14 & - & $3: 01$ & 0.19 & 0.66 \\
F3-37 & - & 43 & 15 & $3: 01$ & 0.00 & 0.87 \\
F3-95 & - & 54 & 17 & $3: 01$ & 0.00 & 0.89 \\
\hline
\end{tabular}


different expression of resistance and modes of inheritance, are involved in the response to this fungus. Observed segregation against the local isolate of powdery mildew in the $F_{2}$ and $F_{2: 3}$ segregating populations derived from the cross Porrillo Sintetico (IT0) $\times$ Xana (IT4), can be explained by the presence of two dominant and independent genes in cultivar Porrillo sintético; one gene conferring IT0 (no visible symptoms), and another gene conferring IT3 (limited growth of the pathogen). Both genes show a dominant epistatic relationship. Cultivar Cornell 49242 (IT0) showed the same type of inheritance, although with available data it was not possible to determine if Cornell 49242 and Porrillo Sintético share the same resistance loci. The two segregating populations derived from the cross Porrillo Sintético (IT0) $\times$ X2776 (IT3) showed a good fit to the expected ratio for a dominant gene, confirming that cultivar Porrillo Sintético carries a dominant gene which confers reaction type 0 . The presence of this dominant gene in Porrillo Sintético was also confirmed in the introgression of complete resistance (IT0) to powdery mildew into line $\mathrm{X} 2776$ using backcrossing method. A total of $28 \mathrm{BC}_{1} \mathrm{~F}_{1}$ plants [derived from X2776 $\times$ (X2776 $\times$ Porrillo Sintético)] were tested and a 1:1 segregation ratio was observed (12 plants IT0: 14 plants IT3). Segregating populations derived from the cross X2776 (IT3) $\times$ G122 (IT4) also showed a good fit to the expected ratio of one dominant gene, indicating that line X2776 carries one dominant gene conferring IT3. From these results, it can also be concluded that a dominant gene controls IT3 in genotype X2776, and this gene is also present in Porrillo Sintético. The 9:7 ratio observed in the population derived from Amanda (IT0) $\times$ Xana (IT4) indicates that two complementary genes are involved in the resistance of cultivar Amanda. This type of inheritance has already been described in the interactions powdery mildew-common bean (Ferreira et al. 1999), anthracnose-common bean (Campa et al. 2011), and angular leaf spot-common bean (Mahuku et al. 2011). Additional analysis including allelic tests and mapping will be necessary to characterize the different resistance genes described in this study.

In conclusion, the results of this study (i) show that reactions of common bean genotypes against powdery mildew in controlled conditions can be classified in a 0-4 qualitative scale, (ii) provide clear evidence about a qualitative nature of resistance involving different modes of inheritance, and (iii) identify useful sources of complete and incomplete resistance against the pathogen. This information can be relevant for plant pathologist or the implementation of breeding programs focused on the development of new cultivars carrying genetic resistance to powdery mildew.

Acknowledgments This work was supported by grant RTA2009-093 from INIA-Ministerio de Ciencia y Tecnología, Spain. Noemí Trabanco was the recipient of a salary fellowship from Instituto Nacional de Investigación y Tecnología Agraria y Alimentaria (INIA, Spain).

\section{References}

Almeida AMR, Binneck E, Piuga FF, Marin SRR, do Ribeiro Valle PRZ, Silveira CZ (2008) Characterization of powdery mildews strains from soybean, bean, sunflower, and weeds in Brazil using rDNA-ITS sequences. Trop Plant Pathol 33:20-26

Bett KE, Michaels TE (1995) A two-gene model for powdery mildew resistance in common bean. Annu Rep Bean Improv Coop 38:145-146

Campa A, Ferreira JJ, Giraldez R (2011) Genetic analysis of the resistance to eight anthracnose races in the common bean differential cultivar Kaboon. Phytopathology 101:757-764

Drijfhout E (1978) Genetic interaction between Phaseolus vulgaris and bean common mosaic virus with implications for strain identification and breeding for resistance. Agric Res Rep 872, Agic. Univ., Wageningen

Dundas B (1936) Inheritance of resistance to powdery mildew in beans. Hilgardia 10:243-253

Ferreira RV, Ramalho MAP, Corte HR (1999) Genetic control of common bean (Phaseolus vulgaris L.) resistance to powdery mildew (Erysiphe polygoni). Genet Mol Biol 22:233-236

Ferreira RV, Bosco dos Santos J, Patto MA, Furtado D (2001) Agronomical characters and RAPD markers associated with the resistant allele to the Erysiphe polygoni in common bean. Crop Breed Appl Biot 1:11-21

Ferreira JJ, Campa A, Pérez-Vega E, Giraldez R (2008) Reaction of a bean germplasm collection against five races of Colletotrichum lindemuthianum identified in northern Spain and implications for breeding. Plant Dis 92:705-708

Fondevilla S, Carver TLW, Moreno MT, Rubiales D (2006) Macroscopic and histological characterization of genes er 1 and $e r 2$ for powdery mildew resistance in pea. Eur J Plant Pathol 115:309-321

Fondevilla S, Rubiales D, Moreno MT, Torres AM (2008) Identification and validation of RAPD and SCAR markers linked to the gene Er3 conferring resistance to Erysiphe pisi DC in pea. Mol Breeding 22:193-200

Freyre R, Skroch PW, Geffroy V, Adam-Blondon AF, Shirmohamadali A, Johnson WC, Llaca V, Nodari RO, Pereira PA, Tsai SM, Tohme J, Dron M, Nienhuis J, Vallejos CE, Gepts P (1998) Towards an integrated linkage map of 
common bean. 4. Development of a core linkage map and alignment of RFLP maps. Theor Appl Genet 97:847-856

Gepts P, Osborn TC, Rashka K, Bliss FA (1986) Phaseolinprotein variability in wild forms and landraces of the common bean (Phaseolus vulgaris): evidence for multiple centers of domestication. Econ Bot 40:451-468

Kang S-T, Rouf Mian MA (2010) Genetic map of the powdery mildew resistance gene in soybean PI243540. Genome 53:400-405

Katoch V, Sharma S, Pathania S, Banayal DK, Sharma SK, Rathour R (2010) Molecular mapping of pea powdery mildew resistance gene er 2 to pea linkage group III. Mol Breed 25:229-237

Lohnes DG, Bernard RL (1992) Inheritance of resistance to powdery mildew in soybeans. Plant Dis 76:964-965

Mahuku GS, Henríquez MA, Montoya C, Jara C, Teran H, Beebe $S$ (2011) Inheritance and development of molecular markers linked to angular leaf spot resistance genes in the common bean accession G10909. Mol Breed 28:57-71

Mains EB, Dietz SM (1930) Physiologic forms of barley mildew, Erysiphe graminis Hordei Marchal. Phytopathology 20:229-239

Pascual A, Campa A, Pérez-Vega E, Giraldez R, Ferreira JJ (2010) Screening common bean for resistance to four Sclerotinia sclerotiorum isolates collected in northern Spain. Plant Dis 94:885-890

Pastor-Corrales MA (1991) Estandarización de variedades diferenciales y designación de razas de Colletotrichum lindemuthianum (Abstr). Phytopathology 81:694
Pérez-Vega E, Campa A, De la Rosa L, Giraldez R, Ferreira JJ (2009) Genetic diversity in a core collection established from the main bean genebank in Spain. Crop Sci 49:1377-1386

Reddy KS, Pawar SE, Bhatia CR (1994) Inheritance of powdery mildew (Erysiphe polygoni DC) resistance in mungbean (Vigna radiata L. Wilczek). Theor Appl Genet 88:945-948

Román-Avilés B, Kelly JD (2005) Identification of quantitative trait loci conditioning resistance to Fusarium root rot in common beans. Crop Sci 45:1881-1890

Schwartz HF (2005) Powdery mildew. In: Schwartz HF, Steadman JR, Hall R, Forster RL (eds) Compendium of bean diseases, 2nd edn. APS Press, St Paul, pp 36-37

Schwartz HF, Katherman MJ, Thung MDT (1981) Yield response and resistance of dry beans to powdery mildew in Colombia. Plant Dis 65:737-738

Shtaya MJY, Sillero JC, Flath K, Pickering R, Rubiales D (2007) The resistance to leaf rust and powdery mildew of recombinant lines of barley (Hordeum vulgare L.) derived from $H$. vulgare $\times H$. bulbosum crosses. Plant Breed 126:259-267

Sillero JC, Fondevilla S, Davidson J, Vaz Patto MC, Warkentin TD, Thomas J, Rubiales D (2006) Screening techniques and sources of resistance to rusts and mildews in grain legumes. Euphytica 147:255-272

van Hintum ThJL, Brown AHD, Spillane C, Hodgkin T (2000) Core collections of plant genetic resources. IPGRI Tech Bull 3. Int Plant Genet. Resources Inst, Rome 